\title{
Total serum IgE levels among adults patients with intermittent and persistent allergic asthmas
}

\author{
Iris Rengganis, Dirga S. Rambe, Cleopas M. Rumende, Murdani Abdullah
}

Department of Internal Medicine, Faculty of Medicine, Universitas Indonesia, Cipto Mangunkusumo Hospital, Jakarta, Indonesia

\section{ABSTRACT}

Background: Allergic asthma is a chronic inflammatory airway disease mediated by immunologic mechanisms. Based on the degree of severity, allergic asthma is divided into intermittent asthma and persistent asthma. IgE plays an important role in mediating allergic response in asthma; however, there are no studies on total IgE levels in adult asthmatic patients in Indonesia based on disease severity. This study aimed to determine the difference of serum total IgE levels between adult patients with intermittent and persistent allergic asthmas.

Methods: This was a cross-sectional study of allergic asthma patients treated at the Allergy-Immunology Division Polyclinic, Cipto Mangunkusumo Hospital, Jakarta from January to August 2017. The data obtained included the demographic information of the patients, the level of severity of asthma, and the total serum IgE level. The severity level was the independent variable, while the total serum IgE level was the dependent variable. Median difference was analyzed using a Mann-Whitney U test.

Results: There were 60 patients included in this study. Based on the degree of severity, 11 patients (18.3\%) had intermittent asthma and 49 patients (81.67\%) had persistent asthma. The mean (standard deviation) total serum IgE level in all subjects was 42.35 (32.7) IU/ml. Median total serum IgE level was significantly higher in persistent asthma than in intermittent asthma (37 vs. $16 \mathrm{IU} / \mathrm{ml} ; \mathrm{p}=0.004)$.

Conclusion: Serum total IgE levels in persistent allergic asthma patients were significantly higher than in intermittent allergic asthma patients. This finding is consistent with a more severe degree of airway inflammation.

Keywords: allergic asthma, intermittent asthma, persistent asthma, total serum IgE level

pISSN: 0853-1773 • eISSN: 2252-8083 • https://doi.org/10.13181/mji.v27i4.2910 • Med J Indones. 2018;27:279-83

- Received 04 Jun 2018• Accepted 10 Dec 2018

Corresponding author: Iris Rengganis

irisrengganis@yahoo.com

Copyright @ 2018 Authors. This is an open access article distributed under the terms of the Creative Commons Attribution-NonCommercial 4.0 International License (http://creativecommons.org/licenses/by-nc/4.0/), which permits unrestricted non-commercial use, distribution, and reproduction in any medium, provided the original author and source are properly cited. 
Asthma is a heterogeneous disease, characterized by a chronic inflammation of the airway. ${ }^{1}$ Diagnosis of asthma is based on the typical respiratory symptoms and spirometry test. ${ }^{2}$ Based on its severity, asthma is categorized as intermittent and persistent asthmas, which can be further grouped as mild, moderate, and severe. ${ }^{3}$

Allergic asthma is an immunologically mediated asthma, which is orchestrated by the immunoglobulin E (IgE). ${ }^{4}$ Most of the IgE molecules are located in the tissue; the free IgE in the serum is the lowest level of all type of IgE. Although total IgE level is very low in the serum, it is highly biologically active due to its bond with highaffinity receptor (FceRI) in the surface of mast cells and basophils. Allergen binding to IgE and then to FceRI in mast cells or basophils may cause cell degranulation, release inflammatory mediators and cytokines, and result in hypersensitivity symptoms such as plasma extravasation, smooth muscle cell contraction, and itching. ${ }^{5}$

Asthmatic patients showed higher total serum IgE levels than non-asthmatic people. ${ }^{6}$ The normal range for total serum IgE levels is 1.5-144 $\mathrm{kU} / \mathrm{l}(1 \mathrm{kU} / \mathrm{l}=1 \mathrm{IU} / \mathrm{ml}){ }^{7}$ The recommended upper limit for total serum IgE levels is $195.1 \mathrm{IU} / \mathrm{ml}^{8}{ }^{8}$ but other study proposed a value of more than $300 \mathrm{IU} / \mathrm{ml}$ to consider it pathologic. ${ }^{9}$ Specific IgE level to house dust mite in sensitized adults with asthma is directly correlated with settled dust level of these allergens. A correlation was found between the specific IgE allergen level with a range of inflammatory, physiologic, and clinical markers. This suggests the use of indoor allergen-specific IgE levels as potential clinical biomarkers. Some allergen-specific IgE levels could be used for measuring the exposure and the degree of sensitization, and will also relate with the disease severity. ${ }^{10}$ There are no studies on allergen-specific IgE related to asthma severity available in Indonesia. This study aimed to evaluate the serum total IgE levels among adult patients with intermittent and persistent allergic asthmas to explore the role of exposure and sensitization to allergens in the disease severity.

\section{METHODS}

\section{Study design and subjects}

This was a cross-sectional study conducted between January and August 2017 in the Department of Internal Medicine, Faculty of Medicine, Universitas Indonesia-Cipto Mangunkusumo Hospital, Jakarta. Subjects were recruited from the outpatient clinic of Allergy and Clinical Immunology Division. Study subjects were adult allergic asthma patients (19-59 years old), who were invited for serum total IgE testing. Patients were excluded if they were undergoing immunotherapy or had serum total IgE levels less than $10 \mathrm{IU} / \mathrm{ml}$. An oral and a written informed consent were obtained from each patient. Ethical approval was granted by the Ethical Committee of Medical Research, Faculty of Medicine, Universitas Indonesia with Letter No. 53/UN2. F1/ETIK/2017.

\section{Assessment of asthma severity}

Instead of using the Global Initiative for Asthma (GINA) criteria, this study used the 2007 National Institutes of Health (NIH) criteria as described in this paragraph. GINA classifies asthma as mild, moderate, and severe while NIH classifies it as intermittent and persistent. Despite having different terminologies, the two classifications are basically similar.

Every subject went through these steps: history taking, physical examination, spirometry test, skin prick test, serum total IgE test, and asthma severity classification based on the $2007 \mathrm{NIH}$. The data collected from each subject were then processed and analyzed. Intermittent asthma is defined as a degree of asthma where the symptoms occur $<2$ days per week; nocturnal asthma occurs $<2$ days per month; the use of $\beta$ - 2 agonist to relieve the symptoms is $<2$ times per week, with no limitation of normal activities; the lung function predicted forced expiratory volume in 1 second (FEV1) $>80 \%$ and normal FEV1/forced vital capacity (FVC). Persistent asthma is defined as an asthma degree where the symptoms occur $>2$ days per week but not daily; nocturnal asthma occurs $<3-4$ times a month; the use of $\beta_{2}$ agonist to control symptoms is $>2$ times per week, but it is not used daily, and it is not used more than twice a day; minor limitation in normal activities; lung function predicted FEV1 $>80 \%$ and normal FEV1/FVC.

\section{Serum Total IgE Measurement}

Serum total IgE was measured using a commercial kit (Polycheck $^{\circledR}$ Allergy, Biocheck 
Table 1. Characteristics of the study subjects and their clinical comparisons $(n=60)$

\begin{tabular}{|c|c|c|c|c|}
\hline Characteristics & Total $(n=60)$ & Intermittent $(\mathrm{n}=11)$ & Persistent $(n=49)$ & p-value* \\
\hline \multicolumn{5}{|l|}{ Gender, n (\%) } \\
\hline Male & $12(20.0)$ & $2(18.2)$ & $10(20.4)$ & 1.000 \\
\hline Female & $48(80.0)$ & $9(81.8)$ & $39(79.6)$ & \\
\hline Age (years), mean (SD) & $39.2(12.3)$ & $36.8(12.2)$ & $39.8(12.4)$ & \\
\hline \multicolumn{5}{|l|}{ Family history of asthma, n (\%) } \\
\hline Yes & $43(71.7)$ & $7(63,6)$ & $36(73.5)$ & 0.088 \\
\hline No & $17(28.3)$ & $4(36,4)$ & $13(26.5)$ & \\
\hline \multicolumn{5}{|l|}{ Diagnosis, n (\%) } \\
\hline Asthma & $20(33.3)$ & $4(36.4)$ & $16(32.7)$ & 1.000 \\
\hline Asthma and allergic rhinitis & $40(66.7)$ & $7(63.6)$ & $33(67.3)$ & \\
\hline \multicolumn{5}{|l|}{ Persistence, n (\%) } \\
\hline Mild & & & $4(8.2)$ & NA \\
\hline Moderate & & & $22(44.9)$ & \\
\hline Severe & & & $23(46.9)$ & \\
\hline ACT score, mean (SD) & $18.4(5.6)$ & $21.1(4.5)$ & $17.7(5.6)$ & \\
\hline \multicolumn{5}{|l|}{ ACT score group, n (\%) } \\
\hline Well controlled & $11(18.3)$ & $3(27.3)$ & $8(16.3)$ & 0.119 \\
\hline Not well controlled & $16(26.7)$ & $5(45.4)$ & $11(22.4)$ & \\
\hline Uncontrolled & $33(55.0)$ & $3(27.3)$ & $30(61.2)$ & \\
\hline \multicolumn{5}{|l|}{ Corticosteroid use, n (\%) } \\
\hline$<2$ days/ week & $3(5.0)$ & $3(27.3)$ & $0(0)$ & $\mathrm{NA}^{\dagger}$ \\
\hline$\geq 2$ days/ week & $5(8.3)$ & $3(27.3)$ & $2(4.0)$ & \\
\hline 1x/ day & $25(41.7)$ & $3(27.3)$ & $22(44.9)$ & \\
\hline$>1 x /$ day & $27(45.0)$ & $2(18.2)$ & $24(51.0)$ & \\
\hline FEV1/FVC, mean (SD) & $90.7(9.51)$ & $95.3(5.6)$ & $89.7(9.9)$ & $\mathbf{0 . 0 0 8}^{\ddagger}$ \\
\hline FEV1\%, mean (SD) & $66.3(19.4)$ & $84.5(7.6)$ & $62.2(18.9)$ & $<0.001^{\ddagger}$ \\
\hline Total IgE (IU/ml) [median (min & & $16(10-52)$ & $37(11-101)^{\S}$ & $\mathbf{0 . 0 0 4}^{\ddagger}$ \\
\hline
\end{tabular}

*Fisher's exact test; ${ }^{\dagger}$ cannot be calculated due to the presence of zero value; ${ }^{\ddagger}$ Mann-Whitney U test; \$the limit of detection was 100 $\mathrm{IU} / \mathrm{ml}$, values greater than $100 \mathrm{IU} / \mathrm{ml}$ was entered as $101 \mathrm{IU} / \mathrm{ml}$. ACT=asthma control test; FEV1=forced expiratory volume in 1 second, $\mathrm{FVC}=$ forced vital capacity; $\mathrm{SD}=$ standard deviation

GmbH, Münster, Germany) and was performed according to the protocol provided by the manufacturer. Serum from the patient's vein blood was added by a start solution, followed by incubation, washing, and anti-IgE treatment. Then, enzyme conjugate and luminescence reagents were added. The result was read using Biocheck Image Software. The results were expressed in International Units $(\mathrm{IU} / \mathrm{ml})$. The limit of detection was $0.15 \mathrm{IU} / \mathrm{ml}$.

\section{Statistical analysis}

Demographic and clinical profile of the study subjects was presented descriptively. The mean serum total IgE levels were compared between intermittent and persistent asthmas using a Mann-Whitney U test. A p-value of less than 0.05 was considered significant. Analyses were performed using the Statistical Product and Service Solutions (SPSS Inc., Chicago, Illinois, USA) version 17.0 for Windows PC.

\section{RESULTS}

A total of 60 patients were enrolled, with $80 \%$ of them being women. Patients' mean age was 39.2 (12.3) years old. Most patients had both asthma and allergic rhinitis. There were $11(18.3 \%)$ patients with intermittent asthma and $49(81.7 \%)$ patients with persistent asthma. Other characteristics are shown in Table 1. 
The mean total serum IgE levels in all subjects were 42.35 (32.7) IU/ml. Due to skewed data, comparison test was performed using the median values and their intervals. Patients with intermittent and persistent asthmas only showed significant difference in their lung function test. The median difference of serum IgE levels between intermittent and persistent asthmas was statistically significant (Table 1).

\section{DISCUSSION}

Thisstudyaimed toevaluatetheserumtotal IgE levels among adult patients with intermittent and persistent allergic asthmas to explore the role of exposure and sensitization to allergens in the disease severity. The median difference of serum IgE levels between intermittent and persistent asthmas was statistically significant. IgE level is related to the degree of exposure and disease severity. ${ }^{10}$ The higher total IgE levels in persistent asthma compared to intermittent asthma showed an indication that the environmental control is an important factor in treating the diseases. Failure to control the environment results in higher exposure to allergens and persistent asthma. Measuring total IgE levels might act as a biomarker to determine whether efforts to control the environment of suspected allergens was sufficient or need to be reevaluated. In this study, the mean total IgE level was $42.36 \mathrm{IU} /$ $\mathrm{ml}$, while other studies showed higher results. The study in the US found that the mean total IgE among asthmatic patients was $85.2 \mathrm{IU} / \mathrm{ml}$ (95\% confidence interval $[\mathrm{CI}]=80.5-90.1 \mathrm{IU} / \mathrm{ml})$, while a study in Spain had much higher value, i.e. $425 \pm 624 \mathrm{IU} / \mathrm{ml} .{ }^{11}$ Higher mean serum IgE levels were also shown in India $(700 \mathrm{IU} / \mathrm{ml}),{ }^{12}$ Korea $(676.1 \mathrm{IU} / \mathrm{ml}),{ }^{13}$ and Oman $(468 \mathrm{IU} / \mathrm{ml}) .{ }^{14}$

The low total IgE levels in this study might have been caused by the use of inhalant corticosteroid; most of our study subjects $(86.7 \%)$ used this medication at least once a day. Corticosteroid inhalation was chosen as a treatment in asthma management due to its ability to suppress inflammatory reaction thereby reducing asthma symptoms and prevents acute exacerbation. ${ }^{9}$ A double-blind study concluded that the administration of beclomethasone dipropionate at $800 \mathrm{mg}$ per day for 3 months could have significantly reduced total IgE levels and also improved asthma symptoms. Total IgE levels decreased 2 weeks after corticosteroid treatment. ${ }^{9}$ Another possibility that might have caused low total IgE levels was a phenotype called neutrophilic asthma. This phenotype was characterized by eosinophil count of less than $0.5 \times 10^{9} / \mathrm{l}$, serum total IgE total less than 750 $\mathrm{kIU} / \mathrm{l}$, and neutrophil count more than $2.7 \times 10^{9} / \mathrm{l}^{15}$ Neutrophilic asthma did not have pathologic thickening of subepithelial basal membrane, had more severe clinical symptoms, and tended to be steroid-resistant. ${ }^{16}$ It is estimated that $25-50 \%$ asthma cases are neutrophilic. ${ }^{17}$

A study in China involving 3,721 subjects with allergic disease showed that $11.1 \%$ had normal total serum IgE levels despite positive specific IgE. ${ }^{18}$ The characteristic of the atopic condition is the detection of at least one specific IgE examination. This finding suggested that total IgE alone is not sufficient to support allergy diagnosis. Specific IgE should also be checked since it has higher specificity. When total IgE levels increase and specific IgE is positive, the diagnosis of allergic disease is more convincing.

Interpretation of serum total IgE levels in asthmatic patients must be carried out carefully. IgE response can also occur in non-allergic diseases such as helminthiasis, autoimmune diseases, actinic prurigo, and hyper-IgE syndrome. ${ }^{19}$ Normal serum total IgE levels do not exclude the diagnosis of asthma. Serum IgE have short half-life and very low level compared to other immunoglobulins. However, its biological activity is very high because it has strong affinity to the receptors on mast cell or basophils. Therefore, the level of total IgE in the serum does not always reflect the real activity. ${ }^{20}$

Total IgE levels in this study were significantly higher in patients with persistent asthma than those with intermittent asthma. Increasing total IgE levels were also reported among Thai patients in parallel with increasing asthma severity, from intermittent asthma $(785.2 \pm 5.1 \mathrm{IU} / \mathrm{ml})$, moderate persistent asthma $(955.6 \pm 4.6 \mathrm{IU} / \mathrm{ml})$, to severe persistent asthma $(989.4 \pm 4.2 \mathrm{IU} / \mathrm{ml}) .{ }^{21} \mathrm{~A}$ study found that total IgE serum in asthmatic patients was significantly higher than non-asthmatic control (151.95 IU/ $\mathrm{ml}$ vs. $756.26 \mathrm{IU} / \mathrm{ml}$ ); more severe asthma was associated with higher total IgE levels. ${ }^{12}$ Another 
study in Spain showed that the proportion of subjects with more severe asthma and total serum $\mathrm{IgE}>400 \mathrm{IU} / \mathrm{ml}$ was higher than subjects with milder asthma. ${ }^{22}$ All these findings suggested that serum total IgE levels increased proportionally in patients with more severe airway obstruction.

This study had a limitation that the subjects have been diagnosed long prior to the study and have been treated with corticosteroids. Data on corticosteroid used was not assessed and possibly had interfered the total serum IgE measurement. However, despite the high corticosteroid used, total IgE levels showed significant difference between persistent asthma and intermittent asthma.

In conclusion, serum total IgE levels in this study were higher in patients with persistent asthma than in patients with intermittent asthma. Higher IgE level was consistent with more severe inflammatory symptoms.

\section{Conflict of interest}

The authors affirm no conflict of interest in this study.

\section{REFERENCES}

1. Reddel HK, Bateman ED, Becker A, Boulet LP, Cruz AA, Drazen JM, et al. A summary of the new GINA strategy: a roadmap to asthma control. Eur Respir J. 2015;46(3):622-39.

2. Global Initiative on Asthma (GINA) [Internet]. global strategy for asthma management and prevention. [updated 2015; cited 2017 May] Downloaded from: ginasthma.org/wp-content/uploads/2016/01/GINA_ Report_2015_Aug11-1.

3. U.S. Department of Health and Human Services. The National Heart, Lung, and Blood Institute. Guidelines for the diagnosis and management of asthma-expert panel report 3. Bethesda: NHLBI Health Information Center; 2007.

4. Schatz M, Rosenwasser L. The allergic asthma phenotype. J Allergy Clin Immunol Pract. 2014;2(6):645-8.

5. Dullaers M, De Bruyne R, Ramadani F, Gould HJ, Gevaert P, Lambrecht BN. The who, where, and when of IgE in allergic airway disease. J Allergy Clin Immunol. 2012;129(3):635-45.

6. Borish L, Chipps B, Deniz Y, Gujrathi S, Zheng B, Dolan
$\mathrm{CM}$, et al. Total serum IgE levels in a large cohort of patients with severe or difficult-to-treat asthma. Ann Allergy Asthma Immunol. 2005;95(3):247-53.

7. Zetterström 0 , Johansson SG. IgE concentrations measured by PRIST $^{\circledR}$ in serum of healthy adults and in patients with respiratory allergy. A diagnostic approach. Allergy. 1981;36(8):537-47.

8. Woszczek G, Kowalski ML, Borowiec M. Association of asthma and total IgE levels with human leucocyte antigen-DR in patients with grass allergy. Eur Respir J. 2002;20(1):79-85.

9. Barnes PJ, Adcock IM. How do corticosteroids work in asthma? Ann Intern Med. 2003;139(5 Pt 1):359-70.

10. Matsui EC, Sampson HA, Bahnson HT, Gruchalla RS, Pongracic JA, Teach SJ, et al. Allergen-specific IgE as a biomarker of exposure plus sensitization in inner-city adolescents with asthma. Allergy. 2010;65(11):1414-22.

11. Sandeep T, Roopakala MS, Silvia CR, Chandrashekara S, Rao M. Evaluation of serum immunoglobulin E levels in bronchial asthma. Lung India. 2010;27(3):138-40.

12. Chowdary VS, Vinaykumer EC, Rao JJ, Rao R, Babu KR, Rangamani V. A study on serum IgE and eosinophils in respiratory allergy patients. Indian J Allergy Asthma Immunol. 2003;17(1):21-4.

13. Shin HD, Kim LH, Park BL, Jung JH, Kim JY, Chung IY, et al. Association of Eotaxin gene family with asthma and serum total IgE. Hum Mol Gen. 2003;12(11):1279-85.

14. Al-Amri M, Al Rawas OA, Al Riyami BM, Richens ER. Atopy in Omani patients with asthma. J Sci Res Med Sci. 2002;4(1-2):15-23.

15. Chung KF. Neutrophilic asthma: a distinct target for treatment? Lancet Respir Med. 2016;4(10):765-67.

16. Fahy JV. Eosinophilic and neutrophilic inflammation in asthma: insights from clinical studies. Proc Am Thorac Soc. 2009;6(3):256-9.

17. Pavord ID, Brightling CE, Woltmann G, Wardlaw AJ. Non-eosinophilic corticosteroid unresponsive asthma. Lancet. 1999;353(9171):2213-14.

18. Chang ML, Ciu C, Liu YH, Pei LC, Shao B. Analysis of total immunoglobulin $\mathrm{E}$ and specific immunoglobulin E of 3,721 patients with allergic disease. Biomed Rep. 2015;3(4):573-7.

19. Bell RG. IgE, allergies and helminth parasites: a new perspective on an old conundrum. Immunol Cell Biol. 1996;74(4):337-45.

20. Platts-Mills TA. The role of immunoglobulin $\mathrm{E}$ in allergy and asthma. Am J Respir Crit Care Med. 2001;164(8 Pt 2):S1-5.

21. Anupama N, Sharma MV, Nagaraja HS, Bhat MR. The serum immunoglobulin e level reflects the severity of bronchial asthma. Thai J Physiol Sci. 2005;18(3):35-40.

22. Dávila I, Valero A, Entrenas LM, Valveny N, Herráez L, SIGE Study Group. Relationship between serum total IgE and disease severity in patients with allergic asthma in Spain. J Investig Allergol Clin Immunol. 2015;25(2):120-7. 